Lund Observatory. It is hoped that sufficient data will be available later to enable the paths to be computed.

\section{Curious Fading of Comet Gale}

As announced in Nature recently, Comet Gale was found on May 1 by Mr. L. E. Cunningham at Harvard, its magnitude being 10. An orbit and ephemeris were computed, and, knowing the distances of the object from the earth and sun, its magnitude on various dates was estimated. The remarkable thing is that its magnitude is considerably less than that predicted, as the following figures will show :

$\begin{array}{rcc}\text { Date } & \text { Predicted Magnitude } & \text { Observed Magnitude } \\ \text { May } 9 & 9 \cdot 5 & 11 \\ 28 & 8 \cdot 5 & 11 \\ 31 & 8 \cdot 4 & 13\end{array}$

It is probable that some rapid internal changes. on which one can only speculate at the moment, are taking place in the comet.

\section{Announcements}

The Albert Medal for 1938 of the Royal Society of Arts has been awarded to H.M. Queen Mary "in recognition of her Majesty's unremitting interest in arts and manufactures to the great benefit of British industry and commerce". Queen Mary has intimated her acceptance of the medal.

Dr. F. W. Haywood has been appointed chief metallurgist to Wild-Barfield Electric Furnaces, Ltd., to take charge of the new research department nearing completion. Dr. Haywood, who is at present engaged with Messrs. I.C.I. (Fertilizer and Synthetic Products), Ltd., at Billingham, will be commencing his duties later in the year.

Geh. Reg. Rat Heinrich Kayser, emeritus professor of physics at Bonn, and Dr. Hans Horst Meyer, emeritus professor of pharmacology, pathology and biology at Vienna, celebrated their eighty-fifth birthday on March 16 and 17 respectively.

Prof. Paul Fourmarier, professor of physical geography in the University of Liège, has been elected a foreign correspondent of the Geological Society of London.

Prof. M. T. BoGERT, professor of organic chemistry in Columbia University, has been awarded the Priestley Gold Medal of the American Chemical Society. The medal, the highest American honour in chemistry, is granted once in three years. It was established in honour of Joseph Priestley. Priestley lived most of his life in England but went to America late in life to escape hostility to his views as a nonconformist preacher. He lived in Philadelphia and Northumberland, Pa. Alone, and in collaboration with his many students, Prof. Bogert is the author of more than four hundred papers in synthetic organic chemistry.

Mr. J. ReId Morr will give the next Huxley Lecture of the Imperial College of Science and
Technology on May 4, 1939, at 5.30 p.m. The subject of his lecture will be "The Earliest Men".

The tenth International Medical Congress for Psychiatry will be held at Oxford on July 29-August 2. A detailed programme will be published later. Further information can be obtained from Dr. E. B. Strauss, 81 Harley Street, London, W.1.

A national conference on Maternity and Child Welfare will be held in the Great Hall, University of Bristol, on July 5-7, under the presidency of Mr. R. H. Bernays, M.P., Parliamentary Secretary of the Ministry of Health. Further information can be obtained from the Honorary Secretary, Dr. Minett, Carnegie House, 47 Piccadilly, W.1.

ThE next meeting of the French Association for the Advancement of Science will be held at Arcachon on September 22-27 under the presidency of $M$. Guilliermond, member of the Institut de France and professor in the Paris Faculty of Sciences. The subjects for discussion are : (1) the oyster (palæontology, zoology, biology, hygiene, fishing and cultivation); (2) the marine pine and its derivatives ; (3) the pig. ments of living beings (chemical composition and psychological role) (4) biology and protection of fresh water. Further information can be obtained from the Secretary of the Association, 28 rue Serpente, Paris.

THE fifth International Locust Conference will be held in Brussels on August 25-September 1, under the patronage of His Majesty the King of the Belgians. The programme includes discussions on the standardization of studies on phase transformation in locusts ; on methods of studying locust migrations ; on general principles of anti-locust research, etc. The greater part of the programme is devoted to problems of organization of preventive control of locusts and grasshoppers in different natural regions of the world. Information on the Conference can be obtained from the Secretariat, 7 Place Royale, Brussels ; and from the Imperial Institute of Entomology, British Museum (Natural History), London, S.W.7.

WE have received the April issue of Sands, Clays and Minerals, a jourmal edited and produced by A. L. Curtis, Chatteris, which contains a number of interesting papers. One of these deals with the modern uses of tantalum and niobium, another with the reparation of historical buildings, and a third (by A. Barclay, of the Science Museum) is on early technical balances and is profusely illustrated. The journal is of a high standard and contains much information of scientific and economic interest.

Erratum. Prof. J. H. Orton writes that in his letter entitled "Life-History of the Salmon (Salmo salar L.)" in NATURE of June 4, p. 1017, the word "mature" in the bottom line of column 1 was inadvertently written for the word "immature". 